Tér és Társadalom 17. évf. 2003/2. 123-126. p.

Tér és Társadalom

XVII. évf. 2003 2: $123-148$

\title{
KÖNYVJELZÖ
}

\section{EDWARD W. SOJA: POSTMETROPOLIS: CRITICAL STUDIES OF CITIES AND REGIONS}

\author{
(Blackwell Publishers, Oxford, 2001, 440 o.)
}

\section{BAJMÓCY PÉTER}

Edward W. Soja, a kaliforniai UCLA Várostervezési Tanszékének professzora több mint húsz éve kutatja Los Angeles régiója, illetve szélesebben véve a városok és régióik átalakulását kritikai fỏldrajzi szemszögből. Korábbi könyvei a tradicionális politikai gazdaságtan és a modern kritikai kulturális földrajz elemeit ötvözik. Tanulmányai nem csak geográfiai és városépítészeti jellegủek, benne a társadalomkutatók és a filozófusok térszemléletével is találkozhatunk. Legújabb könyve ezeket a különböző megközelítéseket kapcsolja össze, s benne átfogó képet kívản nyújtani a történeti városföldrajzról (geohistory of cities) a kezdetektől napjaink legújabb „fejleményéig”, amelyet „postmetropolis"-nak nevez.

A 20. század utolsó negyede, a posztmodern kor alapvetóen átformálta a fejlett, majd részben az egész világ gazdaságát, társadalmi viszonyait, s ezeken keresztül a nagyvárosok szerkezetét is. A 19-20. század indusztriális metropoliszainak jelentős része az iparszerkezet átalakulásának következtében hanyatlásnak indult, a posztmodern kor új, más típusú városfejlődést hozott. Az átalakulás megítélése egészen szélsőséges álláspontokat is eredményezett a posztmodern városok kutatói között. Amíg egyesek azt állítják, az átalakulás olyan mértékủ, hogy a korábbi idősszakok városkutatásai és azok interpretálásai teljes mértékben használhatatlanok, addig mások szerint a változások a múltban gyökereznek és nem túl mélyek. Miként a modern, indusztriális metropolisz „típuspéldánya" Chicago volt, addig e posztmodern metropolisznak Los Angeles. E város ugyan sok speciális tulajdonsággal rendelkezik (nagy területre szétszóródott önálló települések kusza halmaza, vagy másképpen fogalmazva, hatalmas területre terjed ki, összefolyik a szomszédaival, és nehéz megtalálni a középpontját, éppúgy, mint a geográfiának [Probáld 1989]), ám mégis megszemélyesíti a posztmodern városfejlödés minden egyes jellemzőjét. Los Angeles maga tehát a ,postmetropolis", igy e város fejlődésén, problémáin keresztủl mutatja be Soja a posztmodern városfejlödés sajátosságait.

A Postmetropolis kritikai földrajzi mủ, s ezt a szerző már a bevezetésben hangsúlyozza. Erösíti ezt a könyvben elöforduló számos poszt- előtagú kifejezés (posztmodern, posztmarxista stb.) is. A szerző a legtöbb vonatkozásban elfogadja a kritikai megközelítések főbb alapelveit, ám néhány dolgot eltérően lát, mint más kritikai 
geográfusok. (A kritikai földrajz koránt sem egységes megközelítési mód, viták a kritikai földrajzot múvelök között is szép számmal vannak.) Soja maga is kiemeli, hogy a teret, a területiséget teszi megfigyeléseinek középpontjába, s bár nem negligálja a kritikai társadalomtudományi és/vagy történelmi irányokat, minden vonatkozásban (térbeli igazságosság, területi demokrácia, osztályok, rasszok, nemek területisége) a területiséget keresi. A kritikai megközelítés relatív szabadsága ugyanakkor lehetővé teszi azt is, hogy csak azokra az elemekre koncentráljon, amelyek számára fontosak, így a teljességre való törekvés egyetlen fö fejezetben sem jelenik meg meghatározó szempontként. Ennek az az oka, hogy Soja elsősorban kritikai földrajzi és csak másodsorban városföldrajzi könyvet kívánt írni, így azokat az elemeket emelhette ki a történeti városföldrajz (urban geohistory) tárgyköréböl, amelyek jól beleillettek saját kritikai megközelítésébe.

A "Postmetropolis" kiegészítése, folytatása, továbbgondolása Soja Thirdspace: Journeys to Los Angeles and Other Real-and-Imagined Places („Harmadik tér": Utazások Los Angelesbe és más valós és elképzelt helyekre) c., 1996-ban megjelent művének, egyes fejezetei eredetileg abban jelentek volna meg.

A könyv három fö részre tagolódik. Az első a "Remapping the Geohistory of Cityspace" (A városi terek történetének újra-feltérképezése) címet viseli, és összefoglalja a városi terek történetének a szerzö által legfontosabbnak vélt szakaszait. Három városi forradalomról beszél, az első 10 ezer éve kezdödött DélnyugatÁzsiában (Jerikó, Çatal Hüyük), a második pedig 5-6000 éve indult meg a Termékeny Félhold területén (Ur). A harmadik az ipari forradalom idejére tehetö, és a városi-ipari kapitalizmust eredményezte. A két utóbbi forradalom közötti mintegy 5000 éves időszakot egy mindössze kétoldalas részfejezettel intézi el a szerző, de ennek címe, a találó Fast Forward $\gg$ to the Third Urban Revolution (Elöretekerés [FF $\gg]$ a harmadik városi forradalom felé) sok mindenért kárpótol. A következő fejezet Harvey és Castells alapján írja le az ipari metropoliszok válságát, az ezt követỏ ootödik fejezet ugyanakkor inkább átmenetet képez a második fỏ rész felé, a Los Angeles-i konurbáció fejlödéstörténetét bemutatva ismét igen találó címekkel (the WASPing of LA, the Big Orange explodes stb.).

A "Postmetropolis" második része (Six Discourses on Postmetropolis - Hat értekezés a posztmetropoliszról) hat fejezeten keresztül mutatja be a posztmodern nagyvárosok legfontosabb társadalmi-gazdasági problémáit, elsősorban Los Angeles-i példákon keresztuil. A hat problémakör egyben a posztmetropolisz hat különböző szempontú alternatív leírása is. A posztmodern nagyváros lehet rugalmasan specializált technopoliszokból felépüló posztfordista ipari metropolisz, globalizált városrégió vagy kozmopolisz, szétrobbant posztszuburbán megaváros vagy exopolisz, az egyre intenzívebbé váló társadalmi egyenlőtlenségek, polarizáció által meghatározott fraktál-city, mely Los Angelesnél a szélsőséges etnikai diverzitásban és szegregációban csúcsosodik ki. Az utolsó két megközelítés a társadalmi és térbeli szabályozás módjaira koncentrál, s arra keresi a választ, hogy mi tartja egyben az elözőek alapján szélsőségesen széttagolt posztmetropoliszt? A társadalmi és területi kontroll intenzifikációja az, ami védett, erödített tereket hoz létre a nagyváros valós 
Tér és Társadalom 17. évf. 2003/2. 123-148. p.

és elképzelt veszélyeinek napi világában, $s$ e szigetek összességeként keletkezik az erődített város, az ún. carceral archipelago (Foucault 1977). Végül, az utolsó alternatíva a virtuális vagy kibertérben megjelenô hiperreális Sim-city. A posztmetropolisz különösen bonyolult társadalmi-gazdasági szerkezete csak e hat megközelítés együttes eredőjeként értelmezhetö anélkül, hogy bármelyiket is a többi elé állítanánk. E fejezet bővelkedik leginkább újonnan létrehozott szakkifejezésekben, így a várostípusok elnevezésein túl megjelenik többek között a globalizáció ellentéteként, a kis nemzetállamok dezintegrációjával jellemezhetó balkanizáció, a szuburbiák urbanizációja lévén létrejövő Outer-city, és a Sim-city lakója: a Simicitizen.

A harmadik, egyben legrövidebb fö rész (Lived Space: Rethinking 1992 in Los Angeles - Megélt tér: az 1992-es Los Angeles-i események újragondolása) még az előzőeknél is rendhagyóbb. Egyetlen esemény, az 1992-es Los Angeles-i etnikai zavargások következményein keresztül mutatja be, hogy mi történt a posztmetropoliszban 1992 óta. E rész három fejezetéböl kettő kizárólagosan idézeteken keresztül világítja meg az eseményeket, a különböző szereplők szemszögéből mutatja be az általuk megélt teret - a szerző itt csak lábjegyzetben tesz kiegészítéseket. A mủ nem is lenne igazán kritikai földrajzi, ha az utolsó fejezetet nem annak szentelné a szerző, hogy azonnal megfogalmazza saját kritikáit a „Postmetropolis”-szal kapcsolatban. A posztmetropolisz válsága az 1990-es évek elején elkezdődött. Zavargások törtek ki, szélsöségessé váltak a jövedelmi különbségek, estek az átlagbérek. Megindult a harc a térbeli igazságosság (spatial justice) és a területi demokrácia (regional democracy) megvalósításáert.

A kritikai földrajz sajátossága, hogy kiemelt - az általunk megszokott geográfiai műveknél jóval hangsúlyosabb - szerepet tulajdonít a gondolatoknak, megfogalmazásoknak, a szavaknak. A könyvben többféle aspektusban is megjelenik a szavaknak e kiemelt szerepe. A mủ nyelvezete nem egyszerü, egy hagyományos geográfiai múhöz képest kifejezetten nehezen olvasható, ezt részben a szerző speciális szóhasználata okozza. Soja számos - részben új - jelenségre saját maga alkotott szavakat; ezek magyarra fordítása gyakran lehetetlen, hiszen magyar szövegkörnyezetben az angol nyelvben néhol humorosnak, néhol szellemesnek, néhol ironikusnak tetsző kifejezések nem adják vissza az eredeti hangulatukat. A kifejezések egy része más tudományterületekről (pl. szépirodalom, festészet, filozófia) vagy más nyelvekből (egy-egy közbevetett francia, spanyol, latin vagy német mondat fordítás nélkül) származik. A szavak súlyát indirekt módon emeli ki a kötet ábraanyaga is, hiszen mindössze 18 ábrát közöl a szerzö, többségük inkább csak illusztrációnak tekinthető, s elöfordul, hogy Soja több oldalon keresztül elemez egy olyan ábrát, amely nem is szerepel a könyvben, igaz más müben igen, s erre a szerző pontosan hivatkozik is.

Soja könyve minden szempontból érdekes olvasmány. Egy olyan földrajzi problémát és egy olyan földrajzi megközelítési módot elemez (a posztmodern városfejlỏdés és a kritikai földrajz), melyek alig-alig tủnnek fel a hazai szakirodalomban, miközben a nyugati geográfiában markánsan jelen vannak. Számos új fogalommal, érdekes szakmai kifejezéssel, különleges megközelítési móddal találkozhatunk a 
müben, melyek ma még csaknem teljesen hiányoznak a hazai geográfiából. Soja megközelítése szubjektívnek tünik, ám ez csak látszólagos, mivel a hazai társadalomföldrajzban megjelenö könyvek elsősorban tankönyv-jellegủek vagy tanulmánykötetek, így ritkán találkozhatunk a Postmetropolis-hoz hasonló megközelítésủ mủvel, ahol a szerző egy ismert jelenséget (posztmodern városfejlődés) világít meg a saját nézőpontja szerint. A teljesség igénye nélkül teheti ezt, hiszen a „,kimaradt” területek „,bárhol” elolvashatók. „Bárhol”, ami természetesen alapvetően az angolszász nyelvterületre, illetve a fejlett országokra igaz - Magyarországon a hozzáférést nyelvi, anyagi és technikai korlátok is gátolják. Az efféle megközelítések ma még jelentős részben hiányoznak a nyugati szakirodalomhoz és a rokontudományokhoz képest is kissé talán rugalmatlan magyar társadalomföldrajzból.

\section{Irodalom}

Foucault, M. (1977) Discipline and Punish: The Birth of the Prison. Vintage Books, New York. Probáld F. (1989) Extra Hungariam non est vita? - Tér és Társadalom. 2. 77-80. o. 